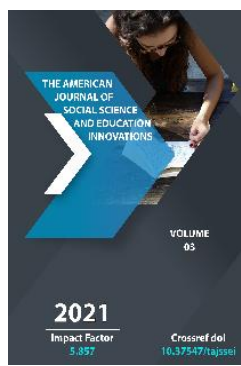

\title{
Protecting Women's Rights And Freedoms In Uzbekistan
}

\author{
Marguba Makhsudovna Nosirova \\ Senior Teacher At The Department "Theory Of Civil Society" Of Andizhan State University, \\ Andizhan Region, Republic Of Uzbekistan
}

\begin{abstract}
Journal Website: http://usajournalshub.c om/index,php/tajssei

Copyright: Original content from this work may be used under the terms of the creative commons attributes 4.0 licence.
\end{abstract}

\section{ABSTRACT}

This article deals with the situation with violations of women's rights and freedoms in the world in recent years and the increase in violence against them during the COVID-19 pandemic, measures taken in our country on gender policy, a number of presidential decrees. The large-scale work on increasing the participation of women in society and the state, based on the tasks set out in the state programs and responded also was analyzed.

\section{KEYWORDS}

Gender Equality, Convention on the Rights of the Child, Early Marriage, Trafficking in Persons, Women, Business and the Law 2020, COVID-19, Beijing Platform.

\section{INTRODUCTION}

UN Secretary-General Antonio Guterres said, "Achieving gender equality and empowering women is an unfinished task of our time and the biggest human rights challenge in the world today". Women make up half of the world's population, which is humanity is equal to half of its potential. Gender equality, which is one of the UN's sustainable development 
goals, is very important for all countries. This is not in vain, because the achievement of gender equality lays the main foundation for achieving sustainable development in all spheres of society. Involving women in community life has been proven to lead to increased productivity and economic growth. Unfortunately, the ancient culture and the traditional view of women as mothers and wives radically worsens the situation of them, especially rural women, leading to further limitations of their opportunities. Gender theory has emerged to address the shortcomings in this area and to make women equal members of civil society based on new, democratic principles.

\section{METHODS}

Gender is derived from the English word "gender", which defines the concept of gender as a social device based on physiological reality $[1, \mathrm{p} .185]$. It is a social aspect of the relationship between women and men that manifests itself in all spheres of life and activity of society, including politics, economics, law, ideology and culture, education and science [2, p.149]. Although the term "gender" is a relatively new concept (1975), it has long been associated with science. In particular, I would like to quote the following views.

\section{RESULTS AND DISCUSSIONS}

Plato's attitude towards women is contradictory. On the negative side, it is manifested in the following: a woman is considered a lowly being, and a man's love for a woman is low, and a man's love for a man is low in the face of friendship. Plato calls a man's love for a woman "Razil Aphrodite" and friendship between men "Razil Aphrodite". He believes that if a man lives a cowardly unhappy life, his soul will pass to the woman after his death. Plato's positive attitude towards women is reflected in his teachings on the ideal state. In this country, women are equal to men in all spheres, in addition to being free from household chores, they are active in public affairs, and men and women are equally responsible for the upbringing of children.

Aristotle (384-322 BC) in his works "Politics", "On the Origin of Animals" and others, the relationship between men and women, their status in society, the division of labor between them, the regulation of population expressed their views on issues such as. According to him, a couple's relationship should be a masterslave relationship. Women and men are not equal beings. The woman gives birth to the child, and the man gives the soul, which is essentially superior. The man rules and the woman obeys [3, p.11-12].

The process of equal rights for women and men has been gaining momentum in our country since the beginning of the 2oth century. Leading enlighteners of the late 19th and early 2oth centuries, M. Behbudi, A. Fitrat, and $\mathrm{A}$. Avloni, spoke extensively about the role of women in society. For example, in his book The Family, Fitrat says, "Women's social and political activism is necessary for national liberation, and women should not be preoccupied only with household chores and child rearing".

While some progress has been made in the last decade, it is clear that humanity still has a long way to go to ensure full equality between men and women in terms of their rights and opportunities. Gender inequality persists in the economic and political spheres. At present, on average, women in the global labor market earn 24\% less than men. As of August 2018, only 24 percent of members of national parliaments worldwide were women. This figure was $11.3 \%$ 
in 1995, indicating a dissatisfaction with the positive dynamics in this regard [4]. As the World Bank Group's Women, Business and Law 2020 study points out, "Equality of opportunity is the best economy". Indeed, it is estimated that women who are lagging behind in employment and entrepreneurship account for 15 percent of the world's GDP.

Nowadays, at least 155 countries around the world have laws on domestic violence, and 140 countries have laws on sexual violence in the workplace. However, even if these laws exist, it does not mean that they will always be implemented or respected in accordance with international standards and recommendations. For example, Article 1, paragraph 1, of the Convention on the Rights of the Child states that for the purposes of this Convention, any person under the age of 18 , is a child " noted. However, in 2019, every fifth woman in the world aged 20-24 was married before the age of 18 . Today, the risk of getting married before reaching the age of majority is highest in subSaharan Africa, where one in three women between the ages of 20 and 24 is married before the age of 18. Underage marriages of girls often lead to early pregnancy and social isolation and stop them from attending school, increasing the risk of domestic violence against the girl [6].

Every day, 137 women are killed by their families around the world. It is estimated that more than half $(50,000)$ of the 87,000 women who were intentionally killed worldwide in 2017 were killed by their loved ones or family members [7, p.10]. More than half of the victims of international human trafficking are women. Adult girls account for 49 percent of trafficking victims worldwide. More than 23 percent of young child trafficking victims are also girls. Together, women and girls make up
72 percent, with the majority of women and girls being trafficked for sexual exploitation [7, p.25-28]. In addition, the decline or loss of income from labor, the loss of remittances from abroad and other sources, the increase in the burden of housekeeping and the increase in domestic violence are also related to lowincome families in urban and rural areas. radically harms the health and living conditions of women. The World Health Organization estimates that one in three women worldwide faces violence in their lives.

The COVID-19 pandemic is exacerbating the process. Restricted movement, marginalization, and economic challenges are exacerbating the vulnerability of women to domestic violence around the world. In some countries, calls to hotlines have quadrupled [8, p.4]. Many national reforms are currently underway around the world to improve the status of women in the workplace, in marriage, and in particular to protect women from violence. In particular, by September 2020, 48 countries around the world have included measures to prevent and combat violence against women in their plans to combat COVID19. In addition, 121 countries have taken steps to increase support and assistance to women who survived violence during the global crisis. The World Bank has been publishing country rankings on gender equality since 2017. Last year, the sixth "Women, Business and Law 2020" training series was published, which analyzed 190 laws and regulations that affect women's economic opportunities. The countries have eight chapters on women's legal wages, employment, running a business, women's asset management, pensions, freedom of movement, marriage and motherhood. evaluated on the basis of the index. The study provides a correlation 
between the level of economic development and gender equality. Belgium, Denmark, France, Iceland, Latvia, Luxembourg, Sweden and Canada are among the top 100 countries in the index.

In recent years, ensuring gender equality, protection of the family, motherhood and childhood, the development of entrepreneurship among women has become one of the priorities of state policy in our country. In particular, the strategy of action includes the issues of increasing the role and place of women and youth in society, ensuring their rights and interests, creating all conditions for them. About half of the country's population - 17 million - are women. In the last four years, significant work has been done to increase the socio-political activity of women and expand their participation in public administration.

In particular, the Decree of the President "On measures to radically improve the activities in the field of support of women and strengthening the institution of the family" was adopted. It was one of the first steps towards a consistent approach to gender equality. Also, the establishment of the Committee on Women and Gender Equality in the Senate, the Presidential Decree "On measures to further strengthen the guarantees of women's labor rights and support entrepreneurship," "On protection of girls from oppression and violence", "On guarantees of equal rights and opportunities for women and men", "Support for women, their active participation in society". The adoption of a number of decrees, resolutions and laws "On measures to further improve the system of participation" has raised the work in this area to a new level. In addition, at the initiative of the President, under the leadership of the Chairman of the Senate of the Oliy Majlis, active work is underway to establish the Republican Women's Public Council. One of the main priorities of the Council is the full support of women, the provisions of the UN Convention on the Elimination of All Forms of Discrimination against Women and the Beijing Platform (1995 4). The 4th World Conference on Gender Equality and Women's Empowerment convened by the United Nations in Beijing, China on September 15. More than 30,000 activists and representatives from 189 countries gathered at the conference to discuss global legal equality known as the Beijing Platform for Action. who have developed a comprehensive plan of achievement.) is to coordinate the implementation of the National Action Plan. In 2020 alone, Uzbekistan adopted 15 normative and legal acts aimed at increasing the role of women in government and society, ensuring their employment, developing women's entrepreneurship and supporting women in need [10]. Over the past period, 950 girls in need of social protection have been admitted to higher education institutions, and 166.3 thousand women have been offered permanent jobs. At the same time, "Women's Entrepreneurship Centers" have been established in each region, soft loans have been allocated by trust funds and commercial banks, more than 224,000 women have been provided with soft loans totaling 6.9 trillion soums. In order to work with women in a targeted way, the "women's book" was published, and the living conditions of more than a thousand women in difficult social situations were improved [11].

It should be noted that a solid legal framework for gender policy has been created in our country. Our work to advance the interests of 
women in all areas is well-recognized internationally. For example, at the UN headquarters, information on Uzbekistan's experience in ensuring women's rights and freedoms in the framework of the Sustainable Development Goals until 2030 was disseminated as an official document of the 75th session of the UN General Assembly on February 23, 2021. The document was published in all official languages of the United Nations and distributed among the member states, as well as placed in the system of official documents of the organization under the number A / 75/773. Secretary General of the International Interparliamentary Assembly Martin Chungong noted that the experience of Uzbekistan will be an experience for other countries. The fact that Uzbekistan has been entrusted with the chairmanship of the Central Asian Leaders' Dialogue this year also shows that gender policy in our country is being pursued in the right direction.

\section{CONCLUSION}

In summary, today the share of women in public administration has reached $26.6 \%$, and in the last elections in the country for the first time in the Legislative Chamber of the Oliy Majlis women accounted for $32 \%$, in the Senate and local councils - 25\%. Currently, about 1,400 women hold leadership positions at the national and regional levels, more than 43,000 at the district and city levels. In particular, the Chairman of the Senate of the Oliy Majlis Tanzila Norbaeva, Adviser to the President of the Republic of Uzbekistan on economic development, investment and foreign trade policy, economist - Galina Saidova, Minister of Preschool Education - Agrepina Shin, Uzbekistan Deputy Prosecutor General of the Republic of Uzbekistan - Svetlana Artikova, Director of the Family Research Center -
Dilorom Tashmuhammedova, Senator, Deputy Hokim of Samarkand region, Chairman of the Women's Committee - Gavhar Alimova, under the Presidential Administration of the Republic of Uzbekistan Saida Mirziyoyeva, Deputy Director of the Agency for Information and Mass Communications, the only woman working in the field of information management in Uzbekistan, Dilnoza Kattakhanova, Deputy Chairman of the Central Council of the Youth Union, Chairman of the Kamalak Children's Organization are prominent women.

Today, Uzbek women are active in all spheres. The recent admission of an ordinary Uzbek girl, Aziza Shonazarova, to Columbia University's tenure track position for the first time among Uzbeks, a lifelong professorship, has filled our hearts with pride. It is necessary to organize regular meetings of students with students in schools, who have a worthy place in such a society and achieve high results in all areas. In turn, it serves as a high role model in the formation of love for science, social activism, initiative in students. In fact, every girl who grows up in an Uzbek family has the potential to achieve such high goals. Only in order to realize their potential, first of all, parents and the whole society should support us. However, the main goal of the gender policy of our country is focused on this issue.

\section{REFERENCES}

1. E.Giddens. Sociology. - Tashkent: Shark, 2002.

2. M.M. Nosirova "Gender equality in Uzbekistan: increase in crime among women and measures to prevent it //Theoretical \& applied science. USA, Philadelphia. 2019. P.49 
3. B.R. Ahmedov. Gender Studies in the Uzbek language. Master's dissertation. Andizhan 2012. Pages 11-12

4. https://www.un.org/ru/sections/issuesdepth/gender-equality/

5. https://www.unwomen.org/en/what-wedo/ending-violence-against-women

6. United Nations, Department of Economic and Social Affairs, Statistics Division (2020). Achieve gender equality and the empowerment of all women and girls.

7. United Nations office on drags and crime. Global study on homicide. Gender-related killing of women and girls. 2019. Page 10

8. United Nations. General Assembly. Strengthen efforts to eliminate all forms of violence against women and girls. Report of the Secretary-General. July 30, 2020 p. 4.

9. UN Women and UNDP (2020).COVID-19 Global Gender Response Tracker .

10. Yangi O'zbekiston. №38(294), 2021-yil 23fevral

11. Yangi O'zbekiston. №36(292), 2021-yil 19fevral 